\title{
Determination of Nine Preservatives in Food Samples by Solid Phase Extraction coupled with Capillary Electrophoresis
}

\author{
Wenjuan Zhang ${ }^{1}$, Fuxiu Yang ${ }^{1}$, Jichao X ${ }^{2}$, Lu Wang ${ }^{1, *}$, Kaowen Zhou ${ }^{1, *}$ \\ ${ }^{1}$ Biochemical Engineering College, Beijing Union University, Beijing 100023, China \\ ${ }^{2}$ Qingdao Institute for Food and Drug Control, Qingdao 266071, China \\ *E-mail: zhoukaowen@ buu.edu.cn, wanglu@buu.edu.cn
}

doi: $10.20964 / 2021.02 .22$

Received: 12 October 2020/ Accepted: 26 November 2020 / Published: 31 December 2020

\begin{abstract}
An efficient method for sample treatment with solid phase extraction (SPE) and separation of components by capillary electrophoresis (CE) for simultaneous determination of nine preservatives in food samples was established. During the SPE, the effects of sample solution $\mathrm{pH}$, extraction time, extraction temperature and salt dosage on extraction efficiency of nine preservatives were studied. The optimized parameters of SPE with $0.2 \mathrm{~g}$ hollow fiber in $10 \mathrm{~mL}$ sample solution were determined as follows: sample solution $\mathrm{pH} 5.5$, extraction time $35 \mathrm{~min}$, extraction temperature $45^{\circ} \mathrm{C}$ and $\mathrm{NaCl} 1.5 \mathrm{~g}$. During the CE separation, the effects of $\mathrm{pH}$ and ionic strength of buffer solution, additional additives and separation voltage on the separation efficiency of eight pair preservatives were investigated. The selected CE separation solution is phosphate buffer solution $(\mathrm{pH}=6.5)$ containing $45 \mathrm{mmol} / \mathrm{L} \mathrm{NaCl}$ and $25 \mathrm{mmol} / \mathrm{L}$ cyclodextrin, and separation voltage is $17 \mathrm{kV}$. All of nine preservatives have good linear relationship. Their detection limits were $0.5-1.0 \mu \mathrm{g} / \mathrm{kg}$. The recoveries of four food samples were $83.2 \%-116.7 \%$. The sensitive and accurate method can be used to determine preservatives in food samples rapidly.
\end{abstract}

Keywords: Preservative, Food sample, Solid phase extraction, Capillary electrophoresis

\section{FULL TEXT}

(C) 2021 The Authors. Published by ESG (www.electrochemsci.org). This article is an open access article distributed under the terms and conditions of the Creative Commons Attribution license (http://creativecommons.org/licenses/by/4.0/). 